\title{
A Case of pseudohypoparathyroidism in a young girl
}

\begin{abstract}
Pseudohypoparathyroidism(PHP) is characterized byhypocalcaemiaandhyperphosphatemia due to parathyroid hormone $(\mathrm{PTH})$ resistance. This hormone resistance is usually caused by mutations in the gene guanine nucleotide-binding protein (GNAS) 1 which encodes the alpha $(\alpha)$ stimulating subunit of the stimulatory G protein (Gsa). These mutations contribute to different forms of the PHP: Type 1a, b, c, pseudopseudohypoparathyroidism and type 2 . We report here a clinical case of a 12-year-old female with suspected PHP type 1a and we discuss her clinical features, radiographic and laboratory findings along with treatment.
\end{abstract}

Keywords: Pseudohypoparathyroidism, End-organ resistance, GNAS cluster, Hypocalcaemia

\section{Case Report}

\author{
Volume 6 Issue 2 - 2018
}

\author{
Manjeeta Baichoo, Anjumanara Omar \\ Department of Paediatrics and Child Health, University of \\ Nairobi, Kenyatta National Hospital, Kenya
}

\begin{abstract}
Correspondence: Manjeeta Baichoo, Department of Paediatrics and Child Health, University of Nairobi, Kenyatta National Hospital, P. O. Box 19676 - Nairobi, Kenya, Tel +254 20 2726300, Ext 43769; Email nairobipaeds@gmail.com
\end{abstract}

Received: December 20, 2015 | Published: March 01, 2018

\section{Introduction}

Pseudohypoparathyroidism (PHP) is caused by end-organ resistance to parathormone $(\mathrm{PTH})$ and is caused by genetic defects in the imprinted GNAS cluster. ${ }^{1-3}$ These gene mutations result in the G-protein inability to activate adenyl cyclase upon binding of PTH to its receptor at the level of the target end organ. Activation of the adenyl cyclase is required for signal transduction that produces the end-organ response to PTH. Failure of signal transduction results in the unresponsiveness of the end organ. The expression of the allele of GNAS 1 gene in humans depends on whether the allele is paternally or maternally inherited and so the disease manifestations also differ depending on which parent passed on the allele. ${ }^{2}$

The type 1a PHP is an autosomal dominant disease and maternal transmission of the mutation (20q13) is required to express type 1a PHP. Type 1a present with a constellation of findings known as Albright's Hereditary Osteodystrophy (AHO) that includes a round facies, short stature, brachydactyly, obesity, subcutaneous calcifications and developmental delay. ${ }^{4}$ Resistance of PTH at the level of the renal tubule leads to the following abnormalities: hyperphosphatemia, hypocalcaemia and secondary hyperparathyroidism. ${ }^{5}$

\section{Case report}

We report a twelve-year-old female who presented to casualty with inability to walk for 3 years, joint stiffness, and painful spasms of upper and lower limbs for four and half years. She is the 8th child of non-consanguinous parents. Her perinatal history was uneventful. Five years ago she initially presented with bilateral cataract and was treated surgically. Five months later she developed spasms of upper and lower limbs and was thought to have epilepsy. She was put on Phenobarbitone, Carbamazepine and Clonazepam. The spasms persisted and were so severe that she even developed a fracture of the right femur during one of the spasms. She developed progressive weakness of the limbs and generalised joint stiffness over the last three years affecting her mobility
On examination, she had delayed eruption of the permanent teeth after loss of the primary dentition. Her weight and height was $24 \mathrm{~kg}$ and $123 \mathrm{~cm}$ respectively both at the 5th centile for her gender and age on the CDC growth chart and her head circumference was $61 \mathrm{~cm}$, above the 97th centile for her age and gender on the CDC chart for head circumferences. She had stiffness of the neck, the temporomandibular joint and of all the upper and lower limb joints. There was shortening of the distal phalanx 3rd to 5th digit as seen by the increased ratio of width of nail to length of nail in Figure 1.

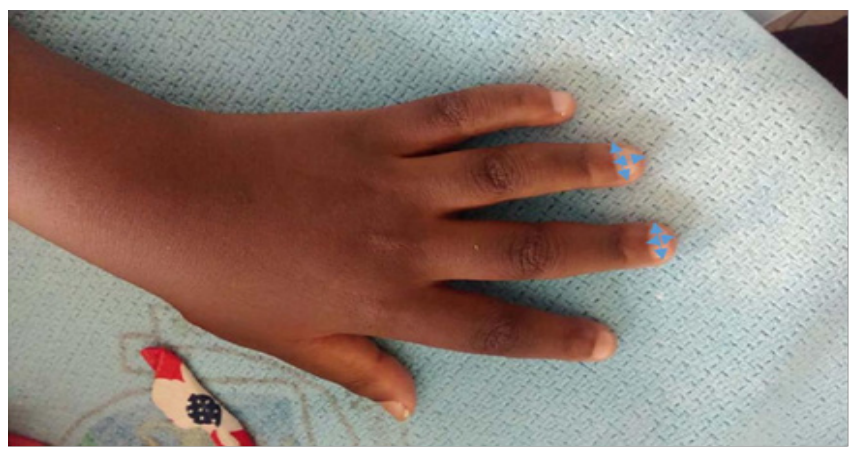

Figure I The increased ratio of width of nail to length of nail in figure.

In the musculoskeletal system, the upper limb and lower limbs was kept in flexion with limited range of movements more in the lower limbs as shown in the Figure 2 below.

The tone was increased in all limbs. There was decreased muscle bulk in bilateral all limbs. Child was able to lift the left leg against gravity but could not lift the right leg. The power in all limbs was $3 / 5$. There was hyperreflexia of all the limbs. Bilateral wrists widening and frontal bossing were also noted in the child. Trousseau sign and chovstek signs were positive. Investigations done showed hypocalcaemia, hyperphosphatemia and elevated

PTH. Biochemistry results are summarised in Table 1. 
Table I Laboratory investigations

\begin{tabular}{|c|c|c|c|c|c|c|}
\hline $\begin{array}{l}\text { Laboratory } \\
\text { investigations in } \\
\text { chronological } \\
\text { order }\end{array}$ & $\begin{array}{c}\text { Magnesium } \\
\text { mmol / I } \\
(\mathrm{N}=0.7-0.86)\end{array}$ & $\begin{array}{c}\text { Vitamin D } \\
25-\text { OH ng/ml } \\
\text { (Deficien-cy < } \\
20 \text { ) }\end{array}$ & $\begin{array}{c}\text { Alkaline } \\
\text { phosphatase } \\
\text { U/L }(\mathbf{N}=42- \\
306)\end{array}$ & $\begin{array}{c}\text { Calcium } \\
\text { level } \mathrm{mmol} / \mathrm{L} \\
(\mathrm{N}=2.1-2.5)\end{array}$ & $\begin{array}{c}\text { Phosphate } \\
\text { levels } \\
\text { mmol/L } \\
(\mathrm{N}=1.3-2.3)\end{array}$ & $\begin{array}{c}\text { Intact } \\
\text { Parathyroid } \\
\text { hormones } \\
\text { pg/mL } \\
(\mathrm{N}=12-65)\end{array}$ \\
\hline I & & & & & & 250 \\
\hline 3 & & & 285 & 1.91 & 2.06 & \\
\hline 4 & & & & & $2.6 \mathrm{I}$ & \\
\hline 5 & 0.69 & 13 & 1575 & & & 336 \\
\hline 6 & & & & 1.68 & & \\
\hline 9 & & & 1499 & $\mathrm{I}, 0$ & 2.67 & \\
\hline 10 & & & $152 \mid$ & 0.9 & 2.18 & \\
\hline
\end{tabular}

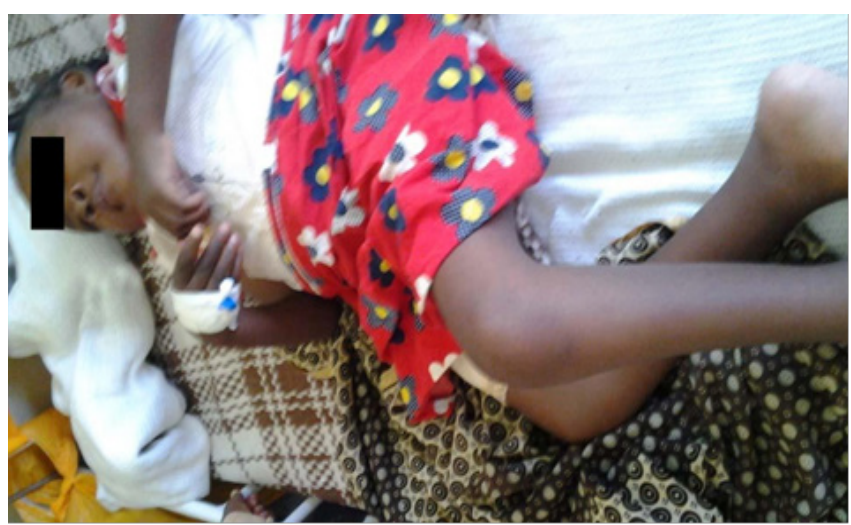

Figure 2 Posture of child.

The serum albumin levels, full blood count, urine analysis, random blood glucose, renal function tests, serum electrolytes and liver function tests were normal.

The X-ray of the wrist as shown in Figure 3 showed cupping and fraying of metaphyseal regions.

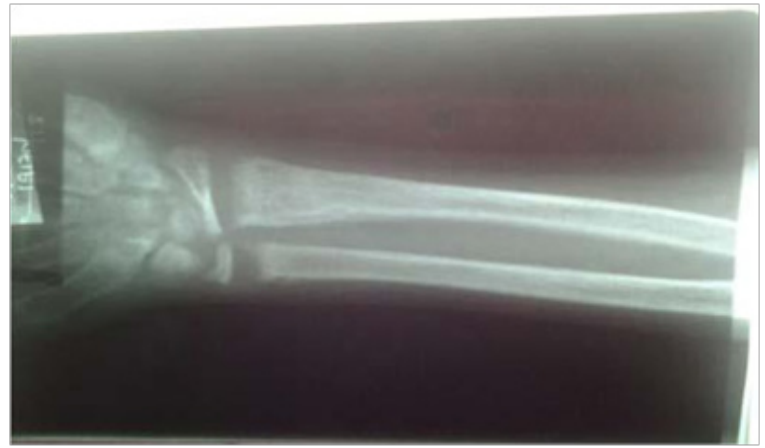

Figure 3 X-ray of the wrist and arm.
The CT-Scan of the cervical spine and the ultrasound abdomen were normal. The CT-Scan of brain showed dense calcifications at the level of bilateral basal ganglia as well as the cortico-medullary junctions of the cerebrum and cerebellum with hyperostosis as seen in Figure 4.

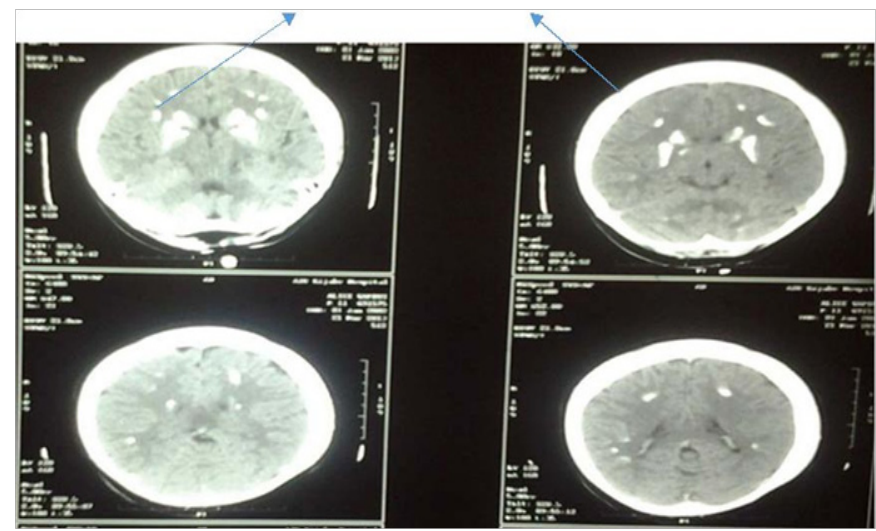

Figure 4 CT-Scan of the brain.

She was managed initially with calcium infusions, aluminium hydroxide and Vitamin D supplements. The calcium levels remained persistently low and parathyroid hormone levels was persistently high and the patient continued to have tetanic convulsions on and off until a serum calcium level of $1.5 \mathrm{mmol} / \mathrm{L}$ was achieved. She continued to have joint stiffness leaving her incapacitated. The main challenge in this patient was the delay in making a diagnosis despite seeking care in different institutions and even having her being diagnosed with epilepsy and treated for hypocalcaemia without improvement.

\section{Discussion}

Pseudohypoparathyroidism is an uncommon disorder. ${ }^{6}$ In 1942, Fuller Albright first used the term, 'pseudohypoparathyroidism' to describe the parathormone resistant hypocalcaemia and hyperphosphatemia. The clinical diagnosis of PHP1a is based on the 
presence of PTH resistance (i.e., hypocalcaemia, hyperphosphatemia, and elevated serum PTH) in association with the features of AHO, which includes short stature, obesity, subcutaneous calcification, mental retardation, round facies, and brachydactyly. ${ }^{5}$ Paraesthesia, numbness, tetany and convulsions are common presentations of severe hypocalcaemia. Classical clinical signs like Chvostek's and Trousseau's sign are useful pointers for hypocalcaemia. ${ }^{7}$ The signs of hypocalcaemia was overlooked in our patient and treated for epilepsy.

Signs of chronic hypocalcaemia includes delayed or absence of permanent tooth eruption, an increase in cavity occurrence and subcapsular cataracts. ${ }^{8,9}$ Hyperostosis was another clinical sign seen in the child. It occurs due to reduced osteoclastic activity, radiologically seen as a dense skeleton and a thickened periosteum due to bone apposition. It affects mainly the long bones, jaw bones and the skull or it can involve the entire skeleton. ${ }^{10-12}$ Approximately $50 \%$ of patients with PHP exhibit localized calcification of the basal ganglia. ${ }^{13-15}$ It was suggested that vascular insufficiency in the extrapyramidal system causes deposition of calcium in the basal ganglia, but there have been no data to definitely support this claim. ${ }^{16,17}$

Although rarely necessary, the demonstration of a blunted response nephrogenous cAMP and phosphate secretion following exogenous PTH administration can contribute to the diagnosis of the type of PHP. ${ }^{918}$ Assays to measure the concentration of the GS alpha subunit of the adenylate cyclase enzyme and molecular genetic testing such as polymerase chain reaction (PCR)-amplified genomic DNA helps to detect mutations in the GNAS1 gene. This gene codifies the subunit $\alpha$ of protein Gs, mapped in chromosome 20q13.2- 20q13.3. ${ }^{1,3,9,19,20}$

PHP is classified into the following types: Type 1a, b, c, pseudopseudohypopara- thyroidism and type 2 . The types and features of PHP is summarised in Table 2.

Table 2 Classification and clinical features of pseudohypoparathyroidism subtypes

\begin{tabular}{|c|c|c|c|c|c|c|c|}
\hline Type & $\begin{array}{l}\text { Calcium } \\
\text { Phosphate }\end{array}$ & $\begin{array}{l}\text { Urinary CAMP } \\
\text { response to PTH }\end{array}$ & PTH & $\begin{array}{c}\text { Gs } \alpha \\
\text { subunit } \\
\text { Deficiency }\end{array}$ & AHO & $\begin{array}{l}\text { Hormonal } \\
\text { resistance }\end{array}$ & Cause \\
\hline PHP - Ia & yes & & & yes & yes & Multiple & Gs mutation \\
\hline PHP - Ib & yes & & & no & no & PTH & $\begin{array}{l}\text { Non-methylation of } \\
\text { promoter IA }\end{array}$ \\
\hline PHP - Ic & yes & & II & no & yes & Multiple & unknown \\
\hline PHP -2 & yes & normal & 川 & no & no & PTH & Acquired defect? \\
\hline PPHP & no & normal & normal & yes & yes & None & Genomic imprinting \\
\hline
\end{tabular}

It was not possible to do molecular genetic testing such as polymerase chain reaction (PCR)-amplified genomic DNA which would have helped to detect mutations in the GNAS1 gene due to cost implications. The presence of hypocalcaemia, hyperphosphatemia and high PTH levels with signs of Albright's hereditary osteodystrophy, pointed to the diagnosis of PHP of type 1a type.

We treated this patient with oral Calcium and an active form of a Vitamin D analogue and noted a partial clinical and laboratory response. She remains on close follow up, with a step up of doses and is on serial clinical and laboratory surveillance.

\section{Acknowledgements}

We thank Dr. Peninah Musyoka and Dr. Lucy Mungai for their contribution in the workup and treatment of our patient.

\section{Conflict of interest}

None.

\section{References}

1. Linglart A, Maupetit-Mehouas S, Silve C, et al. GNAS -Related Lossof-Function Disorders and the Role of Imprinting. Horm Res Paediatr. 2013;79(3):119-129.

2. Bastepe M, Jüppner H. GNAS Locus and Pseudohypoparathyroidism. Hormone Research in Paediatrics. 2005;63(2):65-74.
3. Lemos MC, Thakker RV. GNAS Mutations in Pseudohypoparathyroidism Type 1a and Related Disorders. Human Mutation. 2015;36(1):11-19.

4. Bastepe M, Frohlich LF, Hendy GN, et al. Autosomal dominant pseudohypoparathyroidism type $\mathrm{Ib}$ is associated with a heterozygous microdeletion that likely disrupts a putative imprinting control element of GNAS. The Journal of clinical investigation . 2003;112(8):1255-1263.

5. Kayemba-Kay's S, Tripon C, Heron A, et al. Pseudohypoparathyroidism Type 1A-Subclinical Hypothyroidism and Rapid Weight Gain as Early Clinical Signs: A Clinical Review of 10 Cases. Journal of Clinical Research in Pediatric Endocrinology. 2016;8(4):432-438.

6. Rochtus A, Martin-Trujillo A, Izzi B, et al. Genome-wide DNA methylation analysis of pseudohypoparathyroidism patients with GNAS imprinting defects. Clinical epigenetics. 2016;8:10.

7. Hendy GN, Cole DEC, Bastepe M. Hypoparathyroidism and Pseudohypoparathyroidism. In: De Groot LJ, Beck-Peccoz P, Chrousos G, et al. editors. Endotext. South Dartmouth (MA): MDText.com, Inc.; 2000 .

8. Grajewski RS, Koch KR, Koch H-R, et al. Cataract in pseudohypoparathyroidism. Journal of Cataract \& Refractive Surgery. 42(7):1094-1096.

9. Maeda SS, Fortes EM, Oliveira UM, et al. Hypoparathyroidism and pseudohypoparathyroidism. Arquivos Brasileiros de Endocrinologia \& Metabologia. 2006;50:664-673.

10. Iwai S, Kabata T, Maeda T, et al. Hyperostosis around the acetabulum treated by computer navigation-assisted resection of the ossification: a 
report of two cases. Journal of Orthopaedic Science. 2014;19(2):365370 .

11. Kaynar R, Uludag M, Yalcin N, et al. Hip Pain and Gait Disturbance Associated with Idiopathic Hypoparathyroidism. Journal of clinical and diagnostic research: JCDR. 2016;10(4): RL01.

12. Mak A, Mok CC. Diffuse skeletal hyperostosis and pseudohypoparathyroidism. Rheumatology. 2005;44(2):182.

13. Montenegro AC, Gelenske T, Carvalho ÉH, et al. First description of pseudohypoparathyroidism with frontal lobe calcification and normal serum calcium at the initial manifestation in an otherwise healthy sevenyear-old girl. Arquivos Brasileiros de Endocrinologia \& Metabologia. 2011;55:349-352.

14. Harrington MG, Macpherson P, McIntosh WB, et al. The significance of the incidental finding of basal ganglia calcification on computed tomography. Journal of Neurology, Neurosurgery, and Psychiatry. 1981;44(12):1168-1170.

15. Basak RC. A Case Report of Basal Ganglia Calcification - A Rare Finding of Hypoparathyroidism. Oman Medical Journal. 2009;24(3):220-222.
16. Norman RM, Urich R. The influence of a vascular factor on the distribution of symmetrical cerebral calcification. J Neurol Neurosurg Psychiatry. 1960;23:142-147.

17. Koller WC, Cochran JW, Klawans HL, et al. Calcification of the basal ganglia: computerized tomography and clinical correlation. Neurology. 1979;29(3):328-333.

18. Raghavan P, Katz CM. Pseudohypoparathyroidism type Ia manifesting as intractable epilepsy in a 23-year-old female. International Medical Case Reports Journal. 2012;5:49-54.

19. Yi H-S, Eom YS, Park IB, et al. Identification and characterization of C106R, a novel mutation in the DNA-binding domain of GCMB, in a family with autosomal-dominant hypoparathyroidism. Clinical endocrinology. 2012;76(5):625-633.

20. Patten JL, Johns DR, Valle D, et al. Mutation in the Gene Encoding the Stimulatory G Protein of Adenylate Cyclase in Albright's Hereditary Osteodystrophy. New England Journal of Medicine. 1990;322(20):14121419 . 